\title{
Threats to the brown-throated three-toed sloth Bradypus variegatus Schinz, 1825 (Pilosa: Bradypodidae) in an urban environment in State of Paraíba, Brazil
}

\section{Elaine Pessoa Pedrosa ${ }^{1}, *$, Carla Soraia Soares de Castro ${ }^{1,2}$ and Fabiana Lopes Rocha ${ }^{1,3}$}

\begin{abstract}
${ }^{1}$ Universidade Federal da Paraíba. Centro de Ciências Aplicadas e Educação. Programa de Pós-Graduação em Ecologia e Monitoramento Ambiental. Campus IV, Litoral Norte. Avenida Santa Elizabete, 160. Rio Tinto-PB, Brasil (CEP 58297-000). *Email: ecopessoa_ufpb@yahoo.com.br.

${ }^{2}$ Universidade Federal da Paraíba. Centro de Ciências Aplicadas e Educação. Departamento de Engenharia e Meio Ambiente. Avenida Santa Elizabete, 160. Rio Tinto-PB, Brasil (CEP 58297-000). Email: carla.castro@academico.ufpb.br and csscastro9@gmail.com.

${ }^{3}$ IUCN SSC Center for Species Survival Brazil. Conservation Planning Specialist Group. Parque das Aves. Avenida das Cataratas, 12450. Foz do Iguaçu-PR, Brasil (CEP 85855-750). Email: lopesrocha.fabiana@gmail.com.
\end{abstract}

\begin{abstract}
The brown-throated three-toed sloth Bradypus variegates Schinz, 1825 (Pilosa: Bradypodidae) is an arboreal mammal with wide distribution in the neotropical region. However, the presence of this species in urban environments has attracted attention due to the threats that this environment can offer to this species. In this context, the present study investigated the impacts over brown-throated three toed sloth's population living in an urban area of Rio Tinto, Paraíba, as well as, analyze data from Wildlife Screening Center (Centro de Triagem de Animais Silvestres - CETAS) and the conservation units of Paraíba, to understanding threats and main factors that led individuals to these institutions. From 2011 to 2014 a sloth's population was studied at João Pessoa Square in Rio Tinto. From 2010 to 2015 was analyzed data from CETAS, Guaribas Biological Reserve (GBR), Barra do Rio Mamanguape Environmental Protection Area (BRM-EPA) and Arruda Câmara Municipal Zoobotanical Park (AC-MZP).The place that most registered the receipt of sloths was CETAS (65.5\%), followed by GBR $(17.8 \%)$, AC-MZP (15\%), and BRM-EPA (1.8\%). Offspring were significantly more impacted than adults, because were recorded highest number of injured and dead individuals in CETAS. Offspring not survived also at João Pessoa Square in Rio Tinto (urban environment) until the reproductive phase, due to falls or the rejection of their mothers during parental care. The urbanized matrix causes changes in the parental care of the mother sloths, implying the early abandonment of their offspring. In addition,
\end{abstract}

Received August 15, 2021

Accept August 28, 2021

Released

August 31, 2021

Open Access

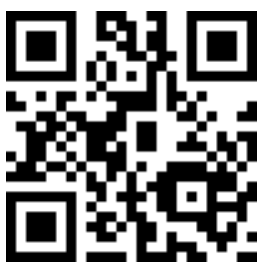

ORCID

(1) 0000-0002-0898-9197 Elaine Pessoa Pedrosa

ISSN 2359-1412/RBGAS-2021-0100/2021/8/19/36/1169 
inadequate introductions of sloths at João Pessoa Square causing malnutrition in individuals due to the lack of insufficient nutrients available, and electric shocks caused by high voltage wires, resulting in death or limb amputation of adult sloths. To minimize these impacts, urban environments needs to be controlled, through tree pruning, prohibit the introductions of sloths and increase the diversity of plant species in this area.

Keywords: Electric shock; Impacts; Parental care; Puppies.

Resumo. Ameaças à preguiça-de-garganta-marrom Bradypus variegatus (Pilosa: Bradypodidae) em ambiente urbano no Estado da Paraíba, Brasil. A preguiça-de-três-dedos-degarganta-marrom Bradypus variegatus Schinz, 1825 (Pilosa: Bradypodidae) é um mamífero arborícola com ampla distribuição na região neotropical. Entretanto, a presença desta espécie em ambientes urbanos, tem atraído a atenção devido às ameaças que estes ambientes podem oferecer para a espécie. Nesse contexto, o presente estudo investigou os impactos sobre uma população de preguiça-de-três-dedos-de-garganta-marrom que vive numa área urbana em Rio Tinto e analisou os dados do CETAS e das unidades de conservação da Paraíba para o entendimento das ameaças e principais fatores que levaram os indivíduos a essas instituições. De 2011 a 2014, a população de preguiça que habita a Praça João Pessoa, em Rio Tinto, foi estudada. De 2010 a 2015 foram analisados os dados coletados pelo CETAS, Reserva Biológica Guaribas, Área de Proteção Ambiental da Barra do Rio Mamanguape e o Parque Zoobotânico Municipal Arruda Câmara. 0 local que mais registrou o recebimento de preguiças foi o CETAS (65,5\%), seguido pela Reserva Biológica Guaribas (17,8\%), Parque Zoobotânico Arruda Câmara (15\%) e Área de Proteção Ambiental da Barra do Rio Mamanguape $(1,8 \%)$. As preguiças jovens são mais impactadas em todos estes locais, uma vez que não conseguem sobreviver no ambiente urbano até a fase reprodutiva, devido às quedas ou pela rejeição de suas mães durante o cuidado parental. A matriz urbanizada provoca alterações no cuidado parental das preguiças mães, implicando no abandono precoce da prole. Além disso, as introduções inadequadas de preguiças na Praça João Pessoa, causam desnutrição nos indivíduos, devido à falta de nutrientes suficientes disponíveis nesta área, bem como os choques elétricos causados pelos fios de alta tensão, resultando na morte ou amputação de membros de preguiças adultas. Para minimizar estes impactos, os ambientes urbanos precisam ser controlados, através de podas das árvores, proibição de introduções de preguiças e aumento da diversidade de espécies vegetais na área.

Palavras-chave: Choques elétricos; Impactos; Cuidado parental; Filhotes.
0000-0002-1070-7187

Carla Soraia Soares de Castro

D) 0000-0003-0819-6290 Fabiana Lopes Rocha 


\section{Introduction}

Brown-throated three-toed sloth Bradypus variegatus Schinz, 1985 (Pilosa: Bradypodidae) is an arboreal mammal, with distribution from Honduras west of the coast of Ecuador, Colombia, Venezuela, Peru, Bolivia, and Brazil (Wetzel and Ávila-Pires, 1980; Wetzel, 1985; Superina et al., 2010). In Brazil, this species is found in the States of Amazonas, Acre, Pará, Rondônia, Maranhão, Tocantins, Mato Grosso do Sul, Paraíba, Pernambuco, Alagoas, Sergipe, Bahia, Espírito Santo, Minas Gerais, Rio de Janeiro, and São Paulo (Moraes-Barros et al., 2010).

The species was considered restricted to the Atlantic and Amazon Forests (Paglia et al., 2012), but Moraes-Barros et al. (2014) suggest B. variegates can be found in Pantanal and Caatinga. Garcia et al. (2017) showed first record of B. variegatus in the Cerrado sensu strict in Minas Gerais. Despite the presence of species in these biomes there are records of small populations isolated in forest fragments (Moraes-Barros et al., 2010; Pedrosa and Castro, 2014; Andrade et al., 2020). Its presence in urban environments also is record (Manchester and Jorge, 2003; Manchester and Jorge, 2009; Silva et al., 2017; Pedrosa and Castro, 2018; Brandão et al., 2019, Andrade et al., 2020), in areas such as public squares and gardens (Pedrosa and Castro, 2018). Consequently, this is associated to the effects of the urbanization process, which modifies landscapes and fragments natural habitats (Pedrosa et al., 2016). In addition, wild animals in urban areas have aesthetic value (Ditchkoff et al., 2006), are charismatics and promotes the possibility of interactions between people and animals (Andrade et al., 2020), as well as are considered by people a cultural patrimony of the city (Pereira et al., 2018).

The threats faced by brown-throated three-toed sloth in urban environments range from capture to the wildlife trade, increase of agonistic interactions (Pedrosa et al., 2018), abandonment of offspring by their mothers (Pedrosa et al., 2018), attacks by domestic dogs, and electric shocks from transmission lines (Xavier et al., 2010; Pedrosa and Castro, 2014; Andrade et al., 2020). Therefore, assessing the potential impacts on the remaining urban sloths populations is fundamental to understand how they are handling life in the urban environments and recommend measures that might mitigate those impacts.

In Brazil, injured wildlife are sent to Wildlife Screening Center (Centro de Triagem de Animais Silvestres - CETAS) administered by the Brazilian Institute of the Environment (Instituto Brasileiro de Meio Ambiente - IBAMA). Wildlife Screening Center receive, identify, mark, triage, evaluate, treat and rehabilitate or otherwise determine the fate of wildlife that are seized during inspections, rescued or voluntarily surrendered by private citizens (Brazilian Normative Instruction No. 169/2008/IBAMA) (Brasil, 2008). There is only one CETAS in Paraíba State; nonetheless, rescued and voluntarily surrendered sloths that are injured or found outside their natural habitat are also handled by Conservation Units as Guaribas Biological Reserve, Barra do Rio Mamanguape Environmental Protection Area, and the Arruda Câmara Municipal Zoobotanical Park at João Pessoa city. Besides managing these animals, these institutions collect data (e.g., age, sex, weight and health status) that have been little explored but can serve to increase information on the biology of brown-throated three-toed sloth and analyze their major threats (Silva et al., 2014).

This study reports impacts under brown-throated three-toed sloth population inhabit in Rio Tinto, State of Paraíba, Northeast Brazil, an urban area. Furthermore, fiveyear data from the Paraíba CETAS and conservation units were compiled and analyzed to increase the understanding of the biology of brown-throated three-toed sloth in urban areas and the main factors that led the individuals to these institutions. Therefore, the hypothesis of this study is that urban environments cause impacts to sloths, since sloths in these areas are vulnerable to electric shocks or being run over, which can cause their

Rev. Bras. Gest. Amb. Sustent., 2021, vol. 8, n. 19, p. 1169-1181. 
death. In addition, another hypothesis is that offspring are more impacted, because the urban environments can influence changes in the parental care from mothers.

\section{Materials and methods}

\section{Study areas}

The sampling was carried out at João Pessoa Square in the Municipality of Rio Tinto; Wildlife Screening Center (CETAS/IBAMA) in the Municipality of Cabedelo; Guaribas Biological Reserve in the Municipalities of Rio Tinto and Mamanguape; Barra do Rio Mamanguape Environmental Protection Area in the Municipality of Rio Tinto; and Arruda Câmara Municipal Zoobotanical Park at João Pessoa City. Square is the main location of the festivals and celebrations in the Municipality of Rio Tinto, and the surrounding area includes streets, a church, bars, restaurants and residences (Figure 1). In the square, inhabit a population of brown-throated three-toed sloth in seven curtain fig Ficus microcarpa Linnaeus, 1782 (Moraceae), with interconnected canopies that occupy an area of 0.26 ha surrounded by a fully urbanized matrix (Pedrosa and Castro, 2014).

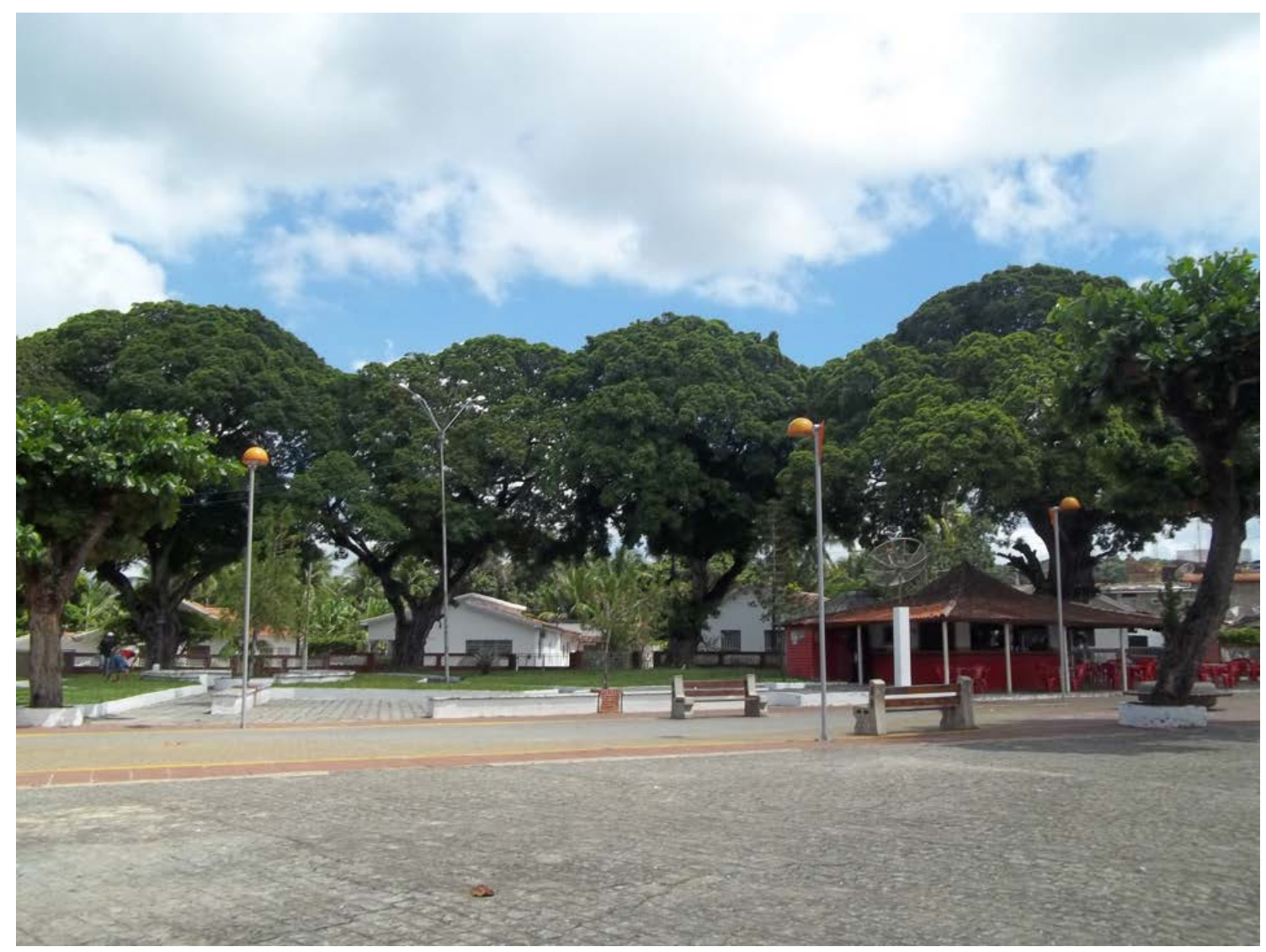

Figure 1. João Pessoa Square where brown-throated three-toed sloth's Bradypus variegatus population was monitored from 2011 to 2014. Municipality of Rio Tinto, Paraíba, Brazil.

João Pessoa square is close $(\sim 1 \mathrm{~km})$ to the Guaribas Biological Reserve (SEMA III) but separated by a fully urbanized matrix, making it impossible for sloths to move to reserve. The Guaribas Biological Reserve is an Integral Protection Conservation Unit that 
is divided into three areas, SEMA I (06 39'47" S; $\left.41^{\circ} 08^{\prime} 00^{\prime \prime} \mathrm{W}\right)$ with 673.64 ha, SEMA II $\left(06^{\circ} 40^{\prime} 40^{\prime \prime} \mathrm{S} ; 4^{\circ} 07^{\prime} 11^{\prime \prime} \mathrm{W}\right)$ with $3,016.09$ ha, located in the Municipality of Mamanguape, and SEMA III ( $06^{\circ} 48^{\prime} 36^{\prime \prime}$ S; $41^{\circ} 45^{\prime} 02^{\prime \prime}$ W), with 338.82 ha, located in the Municipality of Rio Tinto, where it was held the survey. Before becoming a Biological Reserve, these forest fragments belonged to the Legal Reserve of the Integrated Colonization Project of Rio Tinto of the National Institute of Colonization and Agrarian Reform - INCRA (Feijó et al., 2016). In 1990, Guaribas Biological Reserve was created and went through a long history of deforestation and hunting before its creation (Scardua, 2003). The Reserve received the name "Guaribas" in reference to the Alouatta belzebul translocation project, which was of great importance for the implementation of Guaribas Biological Reserve (Feijó et al., 2016).

Barra do Rio Mamanguape Environmental Protection Area is located on the northern coast of Paraíba (6 $6^{\circ} 45^{\prime} 19^{\prime \prime}$ S; $34^{\circ} 59^{\prime} 22^{\prime \prime}$ W), in the Mesoregion of Zona da Mata (Brasil, 1993), covering 65\% of the territory of Rio Tinto (Cury, 2014). This protection area has 14,640 ha, being composed of sedimentary land that can reach up to $10 \mathrm{~m}$, being represented by beaches, dunes, sandbanks, mangroves and reef formations (Carvalho, 1982). CETAS $\left(07^{\circ} 06^{\prime} 26^{\prime \prime} \mathrm{S}\right.$; $\left.4^{\circ} 52^{\prime} 21^{\prime \prime} \mathrm{W}\right)$ is located specifically at Restinga National Forest (Silva, 2016) in Cabedelo, the Metropolitan Region of Municipality of João Pessoa, capital of the State of Paraíba.

The Arruda Câmara Municipal Zoobotanical Park (0706' 26" S; $\left.34^{\circ} 52^{\prime} 38^{\prime \prime} \mathrm{W}\right)$ is located at Municipality of João Pessoa, in the Roger neighborhood. The Zoobotanical Park is formed by small fragments of the Atlantic Forest, with approximately 26 hectares. This park has an institutional policy that allows several visits and activities with audiences of different age groups, education and social class (Andrade et al., 2016).

\section{Brown-throated three-toed sloth population monitoring and counting}

From 2011 to 2014, brown-throated three-toed sloth population inhabit in the curtain fig Ficus microcarpa Linnaeus, 1782 (Moraceae) at João Pessoa Square, in the Municipality of Rio Tinto, Paraiba, were studied. Sloths were observed weekly for 4 hours in the morning (from 8 am to $12 \mathrm{pm}$ ) and in the afternoon (from $1 \mathrm{pm}$ to $5 \mathrm{pm}$ ) on alternate days, but occasional observations made outside the study schedule were also included. Ad libitum observation method (Altmann, 1974) was used to record data on individuals.

The direct counting method which all individuals present in the research's field of view are counted, was used to determine the number of individuals (Brower and Zar, 1984; Queiroz, 1995). Individuals were differentiated by physical characteristics (fur color or patterns), age and sex. In terms of age, an individual under the care of its mother or found alone but still small was considered a young, and a large individual whose sex could be identified based on its fur was considered an adult. Individual with fur color and patterns similar to adult, but smaller size as considered subadult. Males and females were differentiated based on a patch of black fur with orange borders, called speculum that is only present on the backs of males (Wetzel, 1985).

\section{Data analysis}

Records of seized or voluntarily surrendered brown-throated three-toed sloth in Paraíba State for the period of 2010 to 2015 that were collected by CETAS, Guaribas Biological Reserve, Barra do Rio Mamanguape Environmental Protection Area, and Arruda Câmara Municipal Zoobotanical Park were analyzed. The data were standardized considering sex, age and nutritional status of individuals as well as the capture location and the origin/cause of removal and death; the general aspect of individuals upon collection by the environmental institutions was also standardized. Individuals who no apparent impairment, such as wounds, malnutrition, secretions or other signs of illness, 
were considered healthy, whereas individuals that presented any of these symptoms were considered unhealthy. The chi-square test was applied to the data to compare frequencies of healthy and unhealthy individuals at a 5\% level of significance. Each environmental institution records has different information, so not all information was available in all records. In addition, records that included GIS data were georeferenced and a spatial distribution map was created using ArcGIS v 9.3®. Data from animal registry by environmental institutions and the brown-throated-three-toed sloth monitoring at João Pessoa Square were graphically analyzed to determine frequencies and proportions of sloths per type of environment and by sex/age class.

\section{Results}

In the first year of monitoring at João Pessoa square, there were 13 individuals ( 9 adult males, 2 adult females, 1 subadult, and 1 young), and by the final year, this population had increased to 17 individuals adults (14 males and 3 females) due to introductions of new individuals. The sex ratio throughout the study was approximately five males to one female. During the study period, there were 13 deaths including one adult female, one adult male, and all young $(n=11)$, which were due to falls from trees $(n=4)$ and abandonment by the mother $(n=7)$ (Figure 2). Two adult males fell during agonistic interactions but survived the fall without serious injury. However, all falls involving young people occurred due to early abandonment. In 2012, there was only one record of an injured individual involving an adult female who was blind in one eye, but it was not possible to identify the cause of the injury.

From 2010 to 2015 a total of 107 records of brown-throated three-toed sloths were obtained in the region. CETAS was the institution with the highest number of records of the dataset (65.5\%: $n=70$ ), followed by Guaribas Biological Reserve $(17.6 \%: n=8)$. The lowest numbers of records were obtained from the Zoobotanical Park (15\%: $n=26)$, and Barra do Rio Mamanguape Environmental Protection Area (1.8\%: $n=3)$. The largest number of records were of adult females, $37.5 \%(n=40)$, whereas males accounted for $25 \%(n=27)$, young $28 \%(n=30)$ and individuals without sex information $9 \%(n=10)$. There was no significant difference in the frequency of records among the four categories $\left(X^{2}=6.25, d f=4, p=0.181\right)$. Records of deaths were higher among females $(n=8)$ than males $(n=1)$.

Among the municipalities of Paraíba with records of brown-throated three-toed sloth, Metropolitan Region of João Pessoa had the highest number $(n=75)$, followed by Mamanguape $(n=26)$ and Rio Tinto $(n=12)$ (Figure 3). There was a total of 100 records with information regarding the general health of individual sloths at the time of arrival at CETAS, Barra do Rio Mamanguape Environmental Protection Area, Guaribas Biological Reserve and Arruda Câmara Municipal Zoobotanical Park. Most of brown-throated threetoed sloths' individuals seems to be in good health $(54 \% ; n=54)$ and were conducted to be released in the wild. Though, the offspring were significantly more impacted than adults $\left(X^{2}=4, d f=1, p=0.04\right)$, presenting the highest number of records of injured and dead individuals. Death after arrival was also recorded at CETAS, with $12 \%(n=12)$ occurring in young and $11 \%(\mathrm{n}=11)$ in adults. The cause of death was not justified and there was no information on the individual's health status for $10 \%(n=10)$ of the adult and $3 \%(n=3)$ of the young records. 


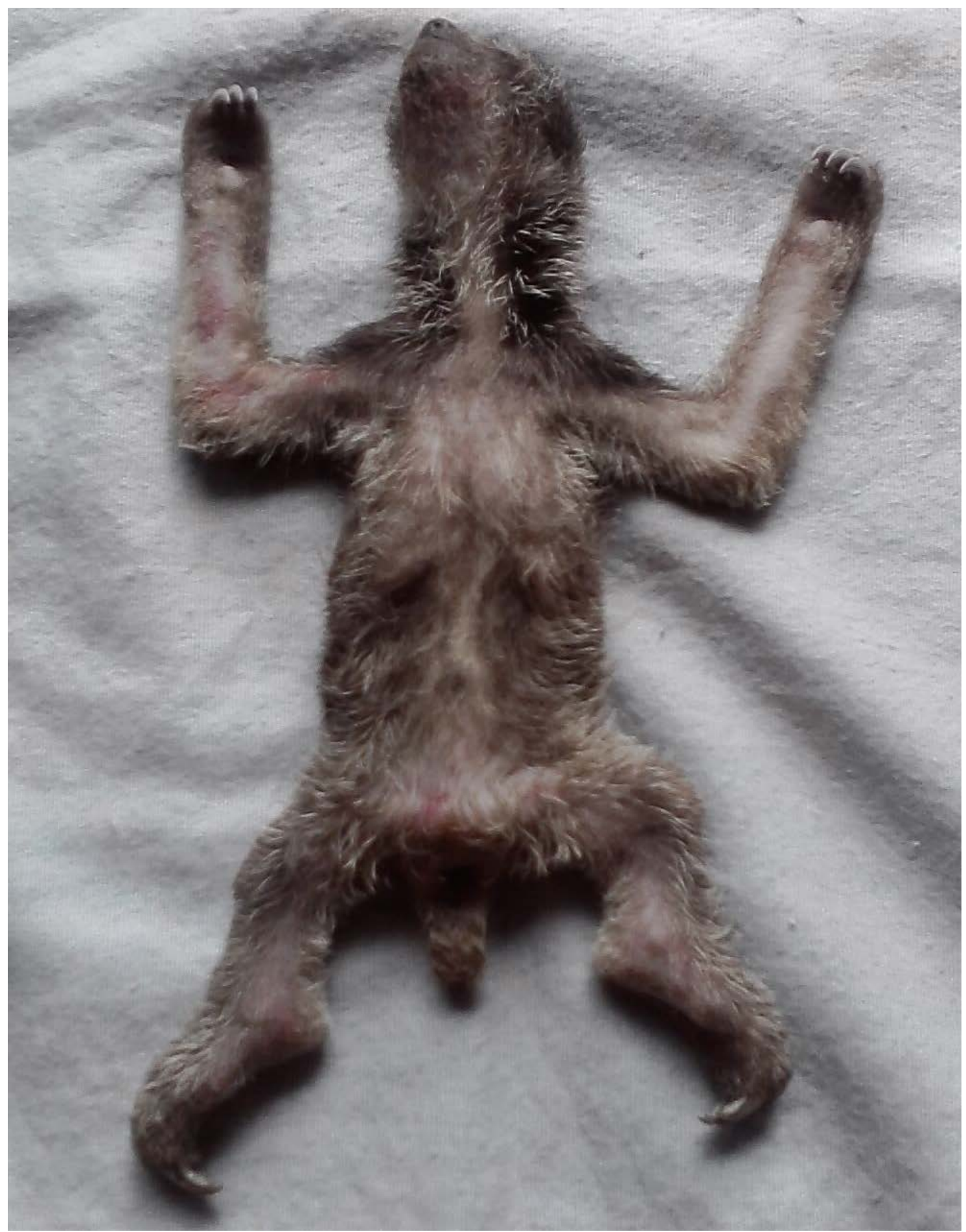

Figure 2. Brown-throated three-toed sloth Bradypus variegatus young dead after being abandoned by its mother at João Pessoa Square, in the Municipality of Rio Tinto, Paraíba State, Brazil.

Few records specified the reason for the rescue and delivery of the individuals to the environmental institutions. Some of these records are of sloths found injured after them falls from trees or electric shock or presenting myiasis. Some records also reported the nutritional status and 18 individuals $(18 \%)$ were considered malnourished. A total of 
43 records included information about the destination of individuals after arrival at CETAS, among them, 37 were adults; 1 was a young; and 5 contained no age information. Only one young survived after being rescued and was insufficiently good condition to be released. The other healthy individuals were released in Restinga National Forest $(n=36)$, Buraquinho Forest $(n=1)$, Guaribas Biological Reserve $(n=2)$, Jacarapé State Park $(n=1)$ and São João sugar refinery $(n=3)$. It is worth mentioning that none of them were examined and placed in quarantine according to the recommended protocols of reintroduction and release of wild animal.
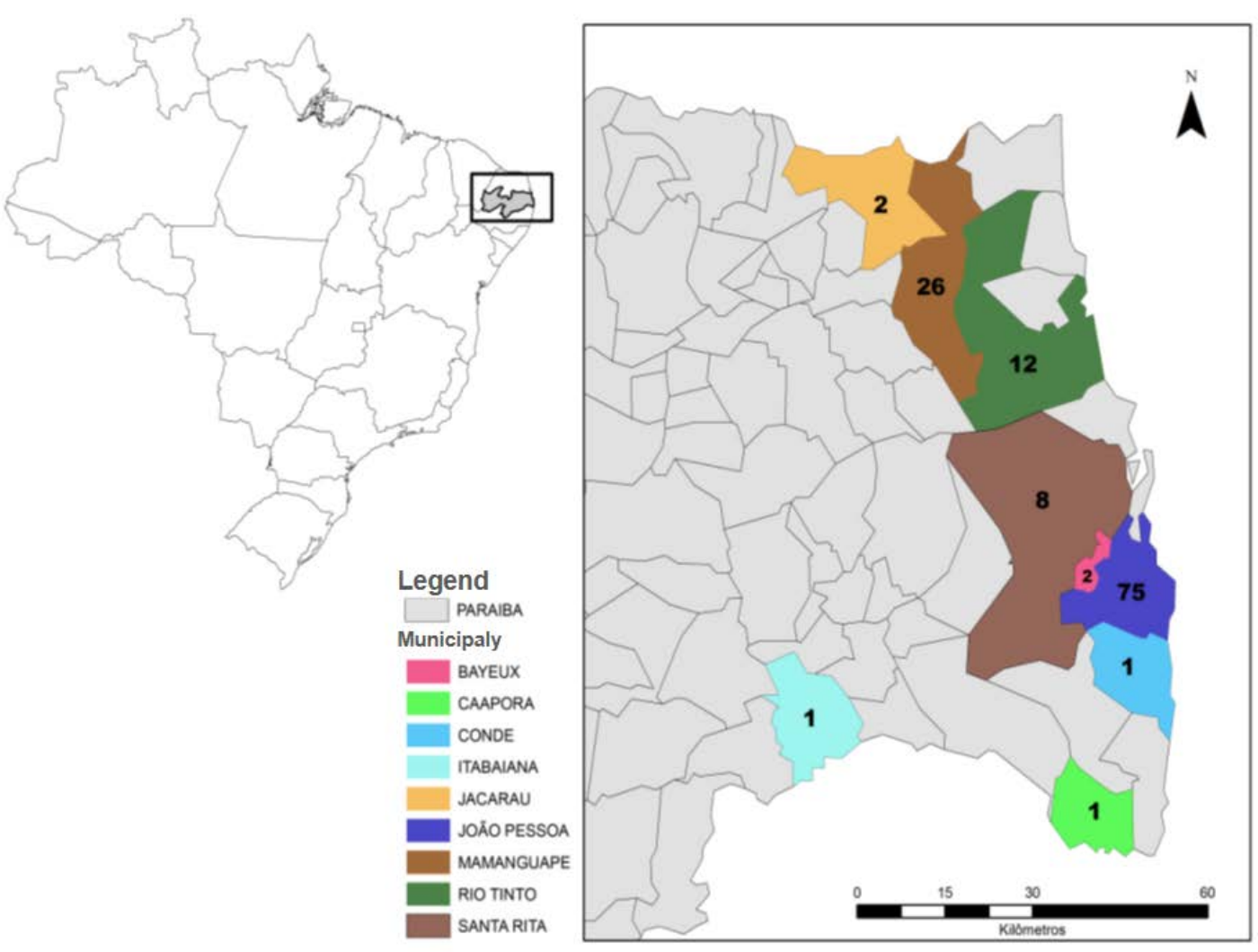

Figure 3. Spatial distribution map with records of brown-throated three-toed sloths Bradypus variegatus in urban environments in the municipalities of Paraíba, Brazil.

\section{Discussion}

Urban environments present multiple threats to brown-throated sloths and young sloths are more significantly impacted. Although many individuals that arrive at CETAS are apparently healthy, many die within a few days of arrival, especially young, which are sensitive to management in captivity due to their strong dependence on the offspringmother relationship. This interaction is highly important to the development of physicalmotor and feeding skills, making it difficult for young to survive after being abandoned (Soares and Carneiro, 2012). Modeling the survival rate during natal dispersal on two-toed (Choloepus hoffmanni) and three-toed (Bradypus variegatus) sloths, Garcés-Restrepo et al. (2018) found a lower survival rate of juveniles, being lowest after maternal independence for both species. 
In addition, the urbanized matrix affects, maternal behavior, which compromises the survival of the young in urban environments (Pinheiro and Esberard, 2012) such as João Pessoa Square. Sloth mothers in their natural environment leave part of their home range at the end of parental care to avoid competition with their offspring and they occupy different portions of their home range during each reproductive cycle (Montgomery and Sunquist, 1978). However, this is impossible in urban environments (e.g. at João Pessoa Square) because sloth mothers are unable to migrate to nearby forest fragments and thus must compete with their offspring for the same resources. Faced with this condition, sloth mothers often abandon young during parental care period, which may be an energy-saving strategy to allocate resources for future reproduction because the physiological cost during the reproductive period affects the survival of females and their future offspring (Hussel, 1972; De Steven, 1980; Moreno, 1989). In this sense, this behavioral change may be a response to competition for resources or problems associated with inbreeding that occur in urban environments (Pinheiro and Esberard, 2012; Pedrosa and Castro, 2014).

In the urban environment sufficient resources are not always available, which could explains the records of malnourished individuals. Urbanized areas have limited plant species diversity, so individuals are subject to food restrictions (Pinheiro, 2015, personal comunication), this condition could also affects sloths from other habitats that are introduced to urban environments, as has been reported for João Pessoa Square (Pedrosa and Castro, 2014). Such introductions compromise the survival of individuals because they only survive for a few months after being removed from their natural habitat (Crandall, 1964). This is one of the reasons that the rehabilitation and release of threethroated sloths is seems as very difficult, because some individuals die within a few days or weeks of arrival at CETAS. One of the main challenges to survival for three-throated sloth after captive management is the difficulty of adapting to a new diet because their diet is essentially folivorous and selective (Queiroz, 1995), as well as, due to their specific nutritional requirements (Montgomery and Sunquist, 1975). In addition to the aforementioned problems, urban areas present other threats, such as power lines and paved streets, and traffic accidents with brown-throated-three-toed sloths can occur.

Among these, the most worrying structures are high-voltage power lines, which are main causes of injuries (Messias-Costa, 2001; Martínez et al., 2004; Lima et al., 2012; Brandão et al., 2019) when a power line is near tree branches, sloths use the wires to move and suffer electric shocks that cause burns, limb amputations and even death.

Immediately it is necessary to adopt strategies to reduce the threats to threethroated sloths in urban environments, considering that translocation of sloths is a complex process that requires planning and monitoring as was very well reported by Chiarelo et al. (2004) in a translocation experiment for the conservation of Bradypus torquatus. The strategies to reduce the threats to three-throated sloths in urban environments include pruning trees to prevent branches from growing too high and reaching high voltage power lines and prohibit introductions of sloth in these areas, as well as, increase diversity of plant species in urban environments to include the species that compose the diet of the three-throated sloth in natural environments.

\section{Acknowledgements}

We thank to Wildlife Screening Centers (CETAS), Guaribas Biological Reserve, Barra do Rio Mamanguape Environmental Protection Area, Arruda Câmara Municipal Zoobotanical Park for the permission to consultation of sloth records. We also thank to 'Coordenação de Aperfeiçoamento de Pessoal de Nível Superior' (CAPES) for the M. Sc. scholarship to Elaine Pessoa Pedrosa and scholarship post doctoral (PNPD/CAPES) to

Fabiana Lopes Rocha. This study had authorization from 'Instituto Chico Mendes de Conservação da Biodiversidade’ ICMBio/SISBIO, by license number 32731-2. 


\section{Conflicts of interest}

The authors declare that have no conflicts of interest.

\section{References}

Altmann, J. Observational study of behavior: Sampling methods. Behavior, v. 49, p. 227-267, 1974. https://doi.org/10.1163/156853974x00534

Andrade, B. F. G.; Luz, M. S.; Silva, M. A. O parque Zoobotânico Arruda Câmara e a alfabetização ecológica do cidadão-turista. Revista Campo do Saber, v. 2, n. 2, p. 128-144, 2016.

Andrade, C. A.; Medeiros, S.; Chiarello, A. G. City sloths and marmosets in Atlantic forest fragments with contrasting levels of anthropogenic disturbance. Mammal Research, v. 65, p. 481-491, 2020. https://doi.org/10.1007/s13364-020-00492-0

Brandão, M. L.; Furtado, M. C.; Albuquerque, D. D.; Cordeiro, J. L. P.; Lourenço, M. C. S.; Figueiredo, F. Management of wild sloths in an anthropized area at Atlantic forest. Oecologia Australis, v. 23, no. 3, p. 644-651, 2019. https://doi.org/10.4257/ oeco.2019.2303.20

Brasil. Instrução Normativa IBAMA no 169, de 20 de fevereiro de 2008. Available from: <http://www.ibama.gov.br/sophia/cnia/legislacao/IBAMA/IN0169-200208.PDF>. Accessed on: May 14, 2020.

Brower, J.; Zar, J. H. Field and laboratory methods for General Ecology. Dubuque: Brown Publishers, 1984.

Carvalho, M. G. R. F. Estado da Paraíba - Classificação geomorfológica. João Pessoa: Editora Universitária/UFPB, 1982.

Chiarello, A. G.; Chivers, D. J.; Bassi, C.; Maciel, M. A. F.; Moreira, L. S.; Bazzalo, M. A translocation experiment for the conservation of maned sloths, Bradypus torquatus (Xenarthra, Bradypodidae). Biology Conservaion, v. 118, no. 4, p. 421-430, 2004. https://doi.org/10.1016/j.biocon.2003.09.019

Crandall, L. S. The management of wild mammals in captivity. Chicago: University of Chicago Press, 1964.

Cury, K. (Coord.). Plano de manejo da Área de Proteção Ambiental da Barra do Rio Mamanguape - Área de Relevante Interesse Ecológico de Manguezais da Foz do Rio Mamanguape. Brasília: ICMBio, 2014. Available from: <https://www.icmbio.gov.br/ portal/images/stories/docs-planos-de-manejo/apa_arie_manguezais_mamanguape2014. pdf>. Accessed on: Jul. 02, 2020.

De Steven, D. Clutch size, breeding success, and parental survival in the trees wallow (Iridoprocne bicolor). Evolution, v. 34, no. 2, p. 278-291, 1980. https://doi.org/10.2307/ 2407392

Ditchkoff, S.; Saalfeld, S. T.; Gibson, C. J. Animal behavior in urban ecosystems: Modifications due to human-induced stress. Urban Ecosystems, v. 9, p. 5-12, 2006. https://doi.org/10.1007/s11252-006-3262-3

Feijó, A; Nunes, H.; Langguth, A. Mamíferos da Reserva Biológica Guaribas, Paraíba, Brasil. Revista Nordestina de Biologia, v. 24, no. 1, p. 57-74, 2016. 
Garcés-Restrepo, M. F.; Pauli, J. N.; Peery, M. Z. Natal dispersal of tree sloths in a humandominated landscape: Implications for tropical biodiversity conservation. Journal of Applied Ecology, v. 55, no. 5, p. 2253-2262, 2018. https://doi.org/10.1111/13652664.13138

Garcia, P. B.; Rodrigues, F. H. G.; Chiarello, A. G. First record of the brown-throated sloth (Bradypus variegatus Schinz, 1825) in the Cerrado of Minas Gerais, Brazil. Edentata, v. 18, p. 73-77, 2017. https://doi.org/10.2305/IUCN.CH.2017.Edentata-18-1.10.en

Hussel, D. T. Factors affecting clutch size in arctic passerines. Ecological Monographs, v. 42, p. 317-364, 1972. https://doi.org/10.2307/1942213

Lima, D. A. S. D.; Lima, W. C.; Rodrigues, M. C.; Quessada, A. M.; Santos, K. M. M.; Moura, C. R. C.; Magalhães, C. S.; Sousa, J. M. Trauma elétrico em preguiça de vida livre: relato de caso. Revista Portuguesa de Ciências Veterinária, v. 107, p. 199-202, 2012.

Manchester, A.; Jorge, W. Biological data of a population of sloths (Bradypus variegatus) in a square of Teófilo Otoni, Minas Gerais, Brazil. Naturalia, v. 23, p. 81-86. 2009.

Manchester, A.; Jorge, W. O efeito da endogamia em uma população de preguiças urbanas (Xenarthra, Bradypus variegatus). Anais do II Congresso Brasileiro de Mastozoologia, Belo Horizonte, 2003. v. 1. p. 204.

Martínez, N.; Antelo, C.; Rumiz, D. I. Rehabilitación de perezosos (Bradypus variegatus) urbanos in reservas privadas aledañas a Santa Cruz de La Sierra: uma iniciativa multipropósito de investigación, manejo y educación. Revista Boliviana de Ecologia y Conservación Ambiental, v. 16, p. 1-10, 2004.

Messias-Costa, A. Medicine and neonatal care of sloths. In: Fowler, M. E.; Cubas, Z. S. (Eds.). Biology, medicine and surgery of South American wild animals. Ames: Iowa State University Press, 2001. p. 247-248.

Montgomery, G.; Sunquist, M. Habitat selection and use by two-toed and three-toed sloths. In: Montgomery, G. (ed.). The ecology of arboreal folivores. Washington: Smithsonian Institution, 1978.

Montgomery, G.; Sunquist, M. Impact of sloths on neotropical energy flow and nutrient cycling. In: Golley, F. B.; Medina, E. (Eds.). Tropical ecological systems, trends in terrestrial and aquatic research. New York: Springer-Verlag, 1975. p. 69-98.

Moraes-Barros, N.; Chiarello, A.; Plese, T. Bradypus variegatus. The IUCN Red List of Threatened Species, 2014. https://doi.org/10.2305/IUCN.UK.2014-1.RLTS.T3038A 47437046.en

Moraes-Barros, N.; Giorgi, A. P.; Silva, S.; Morgante, J. S. Reevaluation of the geographical distribution of Bradypus tridactylus Linnaeus, 1758 and B. variegatus Schinz, 1825. Edentata, v. 11, p. 53-61, 2010. https://doi.org/10.1896/020.011.0110

Moreno, J. Variation in daily energy expenditure in nesting Northern wheatears (Oenanthe oenanthe). The Auk, v. 106, p. 18-25, 1989. https://doi.org/10.2307/4087752

Paglia, A. P.; Fonseca, G. A. B.; Rylands, A. B.; Herrmann, G.; Aguiar, L. M. S.; Chiarello, A. G.; Leite, Y. L. R.; Costa, L. P.; Siciliano, S.; Kierulff, M. C. M.; Mendes, S. L.; Tavares, V. C.; Mittermeier, R. E.; Patton, J. L. Lista anotada dos mamíferos do Brasil. Occasional Papers in Conservation Biology, no. 6, p. 1-76, 2012 
Pedrosa, E. P.; Araújo, A. Z.; Castro, C. S. S. Agonistic interactions in the brown-throated three-toed sloth, Bradypus variegatus (Pilosa: Bradypodidae), in an urban environment in Rio Tinto, Paraíba, Brazil. Edentata, v. 19, p.42-46, 2018. http://doi.org/10.2305/ IUCN.CH.2018

Pedrosa, E. P.; França, R.; Castro, C. S. S. Mudanças na paisagem e impactos da área urbana no comportamento da preguiça-comum (Bradypus variegatus Schinz, 1825) na APA da Barra do Rio Mamanguape, Paraíba, Brasil. In: Almeida, N. V.; Silva, M. D. (Eds.). Geotecnologia e meio ambiente: analisando uma área de proteção ambiental. João Pessoa: F e F Gráfica e Editora, 2016. v. 1. p. 195-219.

Pedrosa, E.; Castro, C. Behavior patterns of the three-toed sloth (Bradypus variegatus Schinz, 1825) in urban and natural environments in Rio Tinto, Paraíba State, Brazil. Brazilian Journal of Ecology, v. 1/2, p. 114-122, 2014.

Pereira, K. F.; Young, R. J.; Boere, V.; Silva, I. O. Urban sloths: Public knowledge, opinions, and interactions. Animals, v. 8, p. 90-100. 2018. https://doi.org/10.3390/ani8060090

Pinheiro, S. D. Personal communication. Associação Programa de Estudo, Manejo e Conservação do Bicho Preguiça. 2015.

Pinheiro, S.; Esberard, C. Alterações no comportamento maternal de preguiças Bradypus variegatus Schinz, 1825. Revista de Etologia, v.1/2, p. 158-158, 2012.

Queiroz, H. L. Preguiças e guaribas: os mamíferos folívoros arborícolas do Mamirauá. Brasília: CNPq e Sociedade Civil Mamirauá, 1995.

Scardua, F. P. (Coord.). Plano de Manejo, Fase 2, Reserva Biológica Guaribas. Brasília: IBAMA, 2003. Available from: <https://www.icmbio.gov.br/portal/images/stories/imgsunidades-coservacao/rebio_guaribas.pdf>. Accessed on: May 14, 2020.

Silva, G. A. O.; Paz, M. C. P.; Cordeiro, T. A. Monitoramento do bicho-preguiça Bradypus variegatus Schinz, 1825 (Xenarthra: Bradypodidae) em um remanescente de Floresta Atlântica (João Pessoa-PB, Nordeste do Brasil). Revista de Gestão Ambiental e Sustentabilidade, v. 4, no. 8, p. 299-312. 2017. https://doi.org/10.21438/rbgas.040805

Silva, R. B. (Coord.). Plano de Manejo da Floresta Nacional Restinga de Cabedelo. Brasília: ICMBio, 2016. Available from: <https://www.icmbio.gov.br/portal/images/ stories/plano-de-manejo/Plano_de_manejo_Flona_Restinga_de_Cabedelo.pdf $>$. Accessed on: May 05, 2020.

Silva, S. M.; Summa, J. L.; Summa, M. E. L.; Geraldi, V. C.; Belluci, M.; Klefasz, A.; Morgante, J. S.; Moraes-Barros, N. Contribution of wildlife governmental centers to conservation and biological study of sloths Bradypus variegatus. Natureza \& Conservação, v. 12, p. 79-85, 2014. https://doi.org/10.4322/natcon.2014.014

Soares, C. A.; Carneiro, R. S. Social behavior between mothers x young of sloths Bradypus variegatus Schinz, 1825 (Xenarthra: Bradypodidae). Brazilian Journal of Biology, v. 62, p. 249-252, 2002. https://doi.org/10.1590/S1519-69842002000200008

Superina, M.; Plese, T.; Moraes-Barros, N.; Abba, A. M. The sloth red list assessment. Edentata, v. 11, p. 115-134, 2010. https://doi.org/10.5537/020.011.0202

Wetzel, R. M. The identification and distribution of recent Xenarthra (Edentata). In: Montgomery, G. (Ed.). The evolution and ecology of armadillos, sloths, and vermilinguas. Washington: Smithsonian Institution Press, 1985. p. 5-21.

Wetzel, R. M.; Ávila-Pires, F. D. Identification and distribution of the recent sloths of Brazil (Edentata). Revista Brasileira de Biologia, v. 40, no. 4, p. 831-836, 1980. 
Xavier, G.; Amora, T.; Valença, Y.; Cabral, M. Apreensões de preguiças Bradypus variegatus Schinz, 1825 e casos de acidentes com choques elétricos envolvendo estes animais na Mesorregião Metropolitana do Recife, Pernambuco. In: Seabra, G.; Novaes, J. A.; Silva, J. N.; Mendonça, T. L. (Eds.). A Conferência da Terra: aquecimento global, sociedade e biodiversidade. João Pessoa: Editora Universitária/UFPB, 2010. v. 1. p. 301-308. 